\title{
The pattern of coastline change based on the characteristics of sediment and coastal slope in Pangenan coast of Cirebon, West Java
}

\author{
Suhendra ${ }^{1}$, Amron Amron ${ }^{1, *}$, and Endang Hilmi ${ }^{2}$ \\ ${ }^{1}$ Marine Science Department, Jenderal Soedirman University 53122 Purwokerto, Indonesia \\ ${ }^{2}$ Aquatic Resources Management Department, Jenderal Soedirman University 53122 Purwokerto, \\ Indonesia
}

\begin{abstract}
The coastline changes depend on stability of coastal bodies, such as characteristics of sediment and coastal slope. This research aimed to determine the relationship between the rate of coastline changes with the characteristics of sediment and coastal slope. The coastline changes were analysed by Landsat satellite images in 1991, 1999 and 2017 used End Point Rate (EPR) method on Digital Shoreline Analysis System (DSAS) module. Sediment characteristics (grain size and sediment statistics mean, sorting, skewness and kurtosis) were analysed by dry sieves and hydrometer with graphical method. The coastal slope used ASTER DEM (Digital Elevation Model) data analysis. The results showed that coastline changes at Pangenan coast of Cirebon in 1991-1999, 1999-2017 and 19912017 had average accretion rate respectively was $10.72 \mathrm{~m} /$ year, 7.25 $\mathrm{m} /$ year, $8.97 \mathrm{~m} /$ year and average abrasion rate was $-12.49 \mathrm{~m} /$ year, -9.67 $\mathrm{m} /$ year, $-6.70 \mathrm{~m} /$ year. The sediments were dominated by coarse silt, that had characteristics, were very well sorted, very fine skewed and platykurtic. The coastal slope was categorized as flat. The conclusion of this research was the rate of coastline change had not significant correlation with sediment and coastal slope.
\end{abstract}

\section{Introduction}

The coastline is a feature line between the land and sea boundaries. The position is not fixed each time, always change continuously based on the coastal condition [1]. A process of abrasion and accretion along the coast can characterize coastline changes. Coastal abrasion occurs when a coast is reduced by sediment causing coastline to be retreat. The accretion occurs when a coastal sediment addition [2]. The dynamics of coastline changes generally occur on the coast of Indonesia, including Pangenan coast. Pangenan coast is located in the east coast of Cirebon Regency, which is generally dominated by the accretion process [3, 4]. However, coastal abrasion occurred in some coastal areas of Cirebon [3].

The main factor-causing coastline changes that is the wave. Waves force the coastal bodies and caused abrasion [5]. However, the power of wave influence in causing coastline

*Corresponding author: twoone_brond@technologist.com 
changes depends on stability of coastal bodies, such as characteristics of sediment and coastal slope. Beaches with flat slope will give a faster effect to the waves in causing coastline changes than the steep beaches [6]. Flat beaches have finer sedimentary characteristics compared to steep beaches [2]. So research on coastline changes associated with the characteristics of sediment and coastal slope is very relevant to do.

The aims of this research are: 1) to determine the rate of change of coastline at Pangenan coast of Cirebon, and 2) to determine the relationship between the rate of coastline change with sediment characteristic and coastal slope at Pangenan coast of Cirebon.

\section{Methods}

The study was conducted based on survey method [7]. The method consists of 3 (three) stages namely the determination of sampling point, data collection and data processing.

\subsection{Study site and sampling point}

This research was conducted at Pangenan coast, Cirebon, West Java with coordinates in $6^{\circ} 45^{\prime} 00^{\prime \prime}-6^{\circ} 48^{\prime} 00^{\prime \prime} S$ and $108^{\circ} 38^{\prime} 00^{\prime \prime}-108^{\circ} 41^{\prime} 00^{\prime \prime}$. Sampling point was determined by 9 points divided into 3 different areas along the study sites using systematic random sampling.

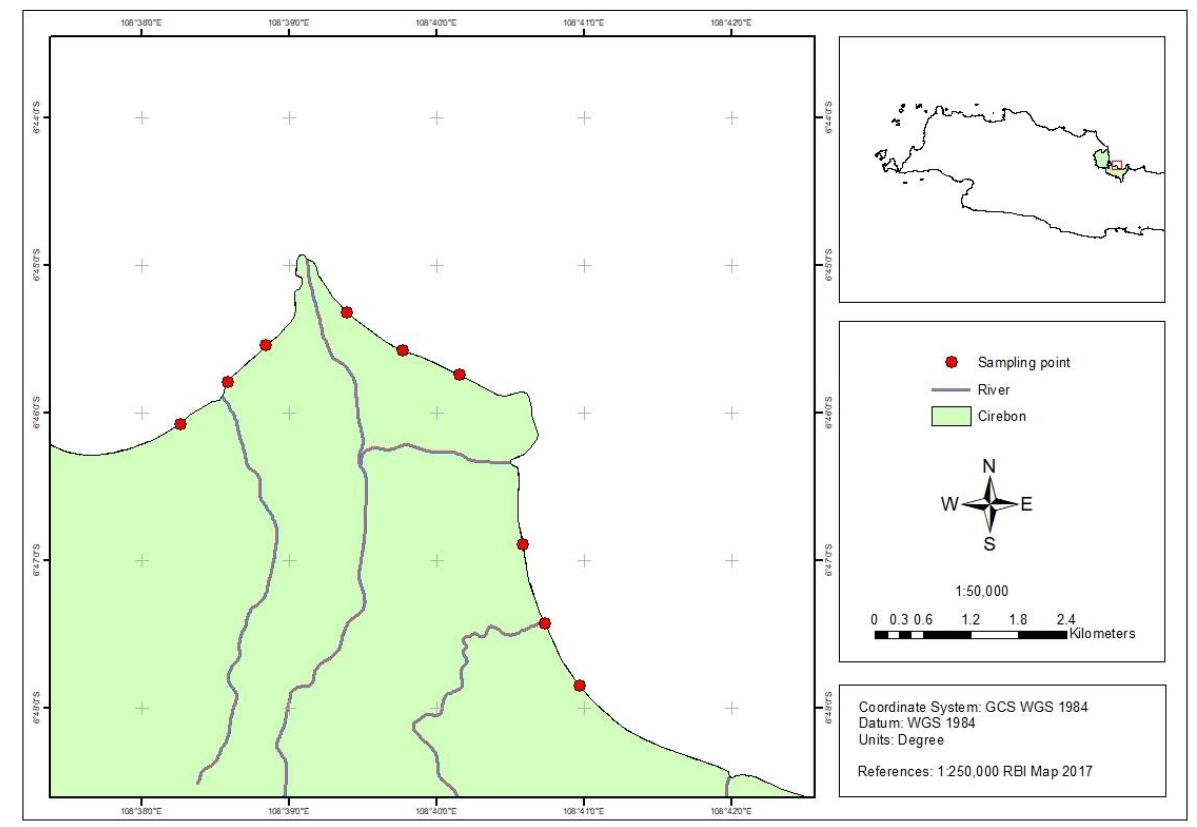

Fig 1. Map of study site and sampling points in Pangenan coast of Cirebon. 


\subsection{Data collection}

Landsat satellite image data of Pangenan Cirebon consisted of images of 1991, 1999 and 2017. Coastal slope data were obtained based on estimates using DEM data. The DEM data used ASTER Global DEM V2 with $30 \times 30$ meters spatial resolution. Both of the data obtained from https://earthexplorer.usgs.gov. Sediment samples was carried out at each point by using a core sampler [7].

Table 1. Landsat image data type used for coastline change analysis.

\begin{tabular}{|c|c|c|c|c|}
\hline \multirow{2}{*}{ Year } & \multirow{2}{*}{ Satellite/sensor } & \multicolumn{2}{|c|}{ Acquisition } & \multirow{2}{*}{ Spatial resolution } \\
\cline { 3 - 4 } & & (dd-mm-yyyy) & (hh:mm:ss) & \\
\hline 1991 & Landsat-5/TM & $05-07-1991$ & $02: 47: 00$ & $30 \mathrm{~m}$ \\
\hline 1999 & Landsat-7/+ETM & $05-09-1999$ & $02: 47: 14$ & $30 \mathrm{~m}$ \\
\hline 2017 & Landsat-8/OLI & $25-05-2017$ & $02: 53: 51$ & $30 \mathrm{~m}$ \\
\hline
\end{tabular}

\subsection{Data processing}

\subsubsection{Coastline data}

Landsat images in 1991, 1991 and 2017 were first processed each time using ER Mapper software which includes: geometric correction, radiometric correction, band stacking and image enhancement [8]. Land and water (sea) boundaries were determined using Band-Ratio method.

Coastal delineation was done by visual interpretation method $[9,10]$. The delineation result of the coastline was performed tidal correction [11].

Coastline data in 1991, 1999 and 2017 were overlayed, so it might be determine the suspected abrasion and accretion area. The coastline changes were analyzed using the Digital Shoreline Analysis System (DSAS) module with the End Point Rate (EPR) method contained in ArcGIS [12]. Then, the data was divided into 9 zones spatially, representing the research station.

\subsubsection{Sediment samples}

Sediment samples analyzed grain size using standard ASTM D 1140-00 and D 422-63 and calculated sediment statistics based on graphical method [13] include Mean size (Mz), Sorting $(\delta 1)$, Skewness $\left(\mathrm{Sk}_{\mathrm{i}}\right)$ and Kurtosis $\left(\mathrm{K}_{\mathrm{G}}\right)$.

\subsubsection{Coastal slope data}

Coastal slope data derived from ASTER GDEM V2 data, processed in ArcGIS software to obtain the average of coastal slope in the study area. The average slopes were classified as flat $\left(<5^{\circ}\right)$, moderate $\left(5^{\circ}-30^{\circ}\right)$ and steep $\left(>30^{\circ}\right)$ [14]. Then, the data was divided into 9 zones spatially, representing the research station. 


\section{Results and discussion}

\subsection{The rate of coastline change}

The rate of coastline change in the study, consisted of accretion and abrasion rate. Accretion rate in Pangenan coast of Cirebon based on Table 3, in 1991-1999 occured in almost all zones except zone 6 and 7 which occured abrasion rates. The average accretion rate in that years was $10.72 \mathrm{~m} /$ year and the average abrasion rate was $-12.49 \mathrm{~m} /$ year. In 1999-2017 and 1991-2017, accretion rate occured in same zone (i.e zone 1, 2, 3, 4) with average respectively was $7.25 \mathrm{~m} /$ year and $8.97 \mathrm{~m} /$ year, also abrasion rate occured in same zone (i.e zone $5,6,7,8,9$ ) with average respectively was $-9.67 \mathrm{~m} /$ year and $-6.70 \mathrm{~m} /$ year. The highest accretion rate in the range 1991-1999 occurred in zone 4 with $15.96 \mathrm{~m} / \mathrm{year}$ accretion and in the range 1999-2017 and 1991-2017 occurred in zone 1 with $11.36 \mathrm{~m} /$ year and $10.46 \mathrm{~m} /$ year accretion. Whereas the highest abrasion rate in all year ranges occurred at zone 6 , with $-19.79 \mathrm{~m} /$ year, $-22.33 \mathrm{~m} /$ year and $-22.53 \mathrm{~m} /$ year abrasion in respectively.

The tendency of the accreted coast was located in the gulf. Whereas the abrasioned coast was located in the promontory [15]. Based on Figure 3, it can be seen that the coastline of zones 1, 2, 3 and 4 from 1991 to 2017 was located in the gulf area which resulted in the accretion process in this area. Whereas the coastline in zones 5 and 6 was located in the promontory, so that in this area occurs the process of abrasion.

Coastlines in zones 7, 8 and 9 which were located in gulf occuring accretion in 19911999, but in 2017 occuring abrasion. It was due to the coastline in 2017 at the area had different effects compared to the other coastline zones. Based on field observation, the coastal seawall had been established, resulting in abnormal coastline changes.

The accretion and abrasion rate in the period between 1991-1999 and 1999-2017 generally decreased. The decreasing in the rate of change of this coastline based on field observation might be caused by changes in coastal morphology with the presence of coastal protective building. In addition, weak oceanographic pressure is also likely to cause a decrease in the rate of coastline change $[16,17]$.

Table 2. The rate of accretion/abrasion in Pangenan coast of Cirebon.

\begin{tabular}{|c|c|c|c|}
\hline \multirow{2}{*}{ Zone } & \multicolumn{3}{|c|}{ Accretion/abrasion (m/year) } \\
\cline { 2 - 4 } & $1991-1999$ & $1999-2017$ & $1991-2017$ \\
\hline 1 & 8.52 & 11.36 & 10.46 \\
\hline 2 & 11.71 & 8.26 & 9.35 \\
\hline 3 & 14.59 & 8.32 & 10.30 \\
\hline 4 & 15.96 & 1.05 & 5.76 \\
\hline 5 & 2.34 & -4.36 & -2.24 \\
\hline 6 & -19.79 & -22.33 & -21.53 \\
\hline 7 & -5.18 & -6.41 & -6.19 \\
\hline 8 & 8.84 & -7.84 & -2.58 \\
\hline 9 & 13.05 & -7.40 & -0.95 \\
\hline Average accretion rate & 10.72 & 7.25 & 8.97 \\
\hline Average abrasion rate & -12.49 & -9.67 & -6.70 \\
\hline
\end{tabular}




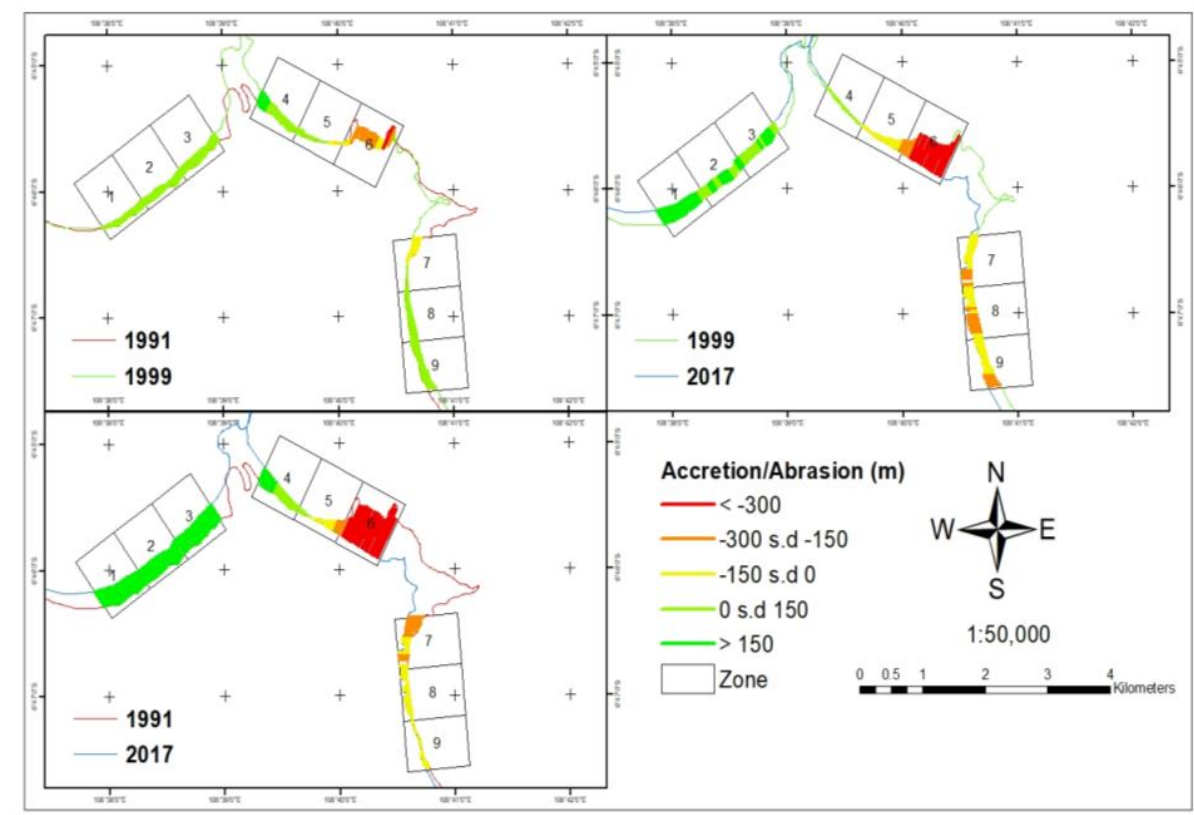

Fig 2. Map of accretion/abrasion in Pangenan coast of Cirebon.

\subsection{The characteristics of sediment}

\subsubsection{Grain size}

Based on Table 4, the coarse silt dominated the sediment type in all stations, with ranging from 29.96 to $70.68 \%$. Whereas the least type of sediment is the granules, with ranging from 0 to $0.81 \%$. If the sediment samples of each station are combined and averaged, then the order of sediment dominance in Pangenan of Cirebon consists of $52.06 \%$ coarse silt, $26.11 \%$ fine silt, $7.5 \%$ fine sand, $6.06 \%$ very fine sand, $5.99 \%$ medium silt, $0.86 \%$ coarse sand, $0.74 \%$ clay, $0.5 \%$ very fine silt and $0.18 \%$ granule.

Table 2. Grain size percentage of coastal sediment type in Pangenan coast of Cirebon.

\begin{tabular}{|l|c|c|c|c|c|c|c|c|c|}
\hline \multirow{2}{*}{ Sediment type } & \multicolumn{10}{|c|}{ Percentage (\%) } \\
\cline { 2 - 11 } & St. 1 & St. 2 & St. 3 & St. 4 & St. 5 & St. 6 & St. 7 & St. 8 & St. 9 \\
\hline Granule & 0 & 0 & 0.06 & 0.81 & 0 & 0.71 & 0.02 & 0 & 0 \\
\hline Coarse sand & 0.07 & 0.08 & 0.73 & 1.25 & 0.35 & 5.13 & 0.12 & 0.03 & 0.01 \\
\hline Fine sand & 0.06 & 0 & 0.33 & 23.87 & 22.4 & 20.38 & 0.2 & 0.13 & 0.09 \\
\hline Very fine sand & 0.14 & 0.19 & 0 & 20.43 & 24.89 & 8.2 & 0.31 & 0.21 & 0.16 \\
\hline Coarse silt & 53.91 & 48.19 & 57.82 & 32.45 & 29.96 & 35.7 & 69.8 & 70.68 & 70 \\
\hline Medium silt & 4.47 & 10.08 & 6.66 & 4.23 & 3.2 & 6.41 & 6.33 & 6.2 & 6.37 \\
\hline Fine silt & 36.88 & 38.09 & 31.07 & 16.95 & 19.2 & 23.49 & 23.21 & 22.75 & 23.36 \\
\hline Very fine silt & 2.24 & 1.12 & 1.11 & 0 & 0 & 0 & 0 & 0 & 0 \\
\hline Clay & 2.24 & 2.24 & 2.22 & 0 & 0 & 0 & 0 & 0 & 0 \\
\hline
\end{tabular}




\subsubsection{Sediment statistics}

Based on the calculation of sediment statistics, the mean size of each station can be seen in Table 5. The mean size produced using unit phi $(\phi)$, Then, classified based on UddenWenworth scale. The mean size at stations 1, 2 and 3 belong to medium silt. The mean size at stations 4,5 and 6 belong to medium sand to very fine sand. And the mean size at stations 7,8 and 9 belong to coarse silt. Other sediment statistic data such as sorting coefficient, skewness and kurtosis can be seen in Table 6 .

The larger mean size indicates the finer types of sediment, the smaller sorting value indicates the better sorted sediment, and the more negatively skewness value indicates the more presence of a large particle size, whereas the more positively indicates the more presence of a small particle size [18]. And the smaller kurtosis value indicates the distribution of sediment is flatter against the normal distribution and vice versa if the larger indicates the peak distribution against the normal distribution [19].

Dominance of mean sizes for medium silt and coarse silt in each of 3 stasions, very well sorted sediment in all stasions and very fine skewed sediment in 4 stasions indicated there was the uniformity of the sediment, an excess of fine particles and dominance of fine sediment type in Pangenan, Cirebon. The sorting value can also indicate the deposition type, the characteristic of deposition current and the deposition time [20]. Because the analyzed sediments showed very fine sorting, so the sediments have sufficient deposition time due to the weak water movement conditions and tend to be stable at the sampling site [18].

The accreted beaches in the study sites tend to be dominated by the average of silt sediments, whereas the abrasioned beaches are dominated by the average of sand sediments. This result contrast with research by [21] who reported that the abrasioned area in Egyptian Nile Delta had a finer characteristic of coastal sediments compared with the accreted area. The difference is probably caused by the presence of river mouths at study sites that contribute to high sedimentation. As reported in the [22] study that there was a significant relationship between coastline changes with sediment transport and runoff.

Table 3. Mean size sediment in Pangenan coast of Cirebon.

\begin{tabular}{|c|c|l|}
\hline Station & Mean & Classification \\
\hline 1 & 5.07 & Medium silt \\
\hline 2 & 5.16 & Medium silt \\
\hline 3 & 5.21 & Medium silt \\
\hline 4 & 3.77 & Medium sand \\
\hline 5 & 3.88 & Very fine sand \\
\hline 6 & 3.95 & Very fine sand \\
\hline 7 & 4.82 & Coarse sand \\
\hline 8 & 4.84 & Coarse sand \\
\hline 9 & 4.82 & Coarse sand \\
\hline
\end{tabular}


Table 4. Mean size sediment in Pangenan coast of Cirebon.

\begin{tabular}{|c|c|l|c|l|c|l|}
\hline \multirow{2}{*}{ Station } & \multicolumn{2}{|c|}{ Sorting } & \multicolumn{2}{|c|}{ Skewness } & \multicolumn{2}{c|}{ Kurtosis } \\
\cline { 2 - 7 } & $\delta 1$ & Classification & $\mathrm{Sk}_{1}$ & Classification & $\mathrm{K}_{\mathrm{G}}$ & Classification \\
\hline 1 & 5.07 & Medium silt & -0.28 & fine skewed & 0.65 & very platykurtic \\
\hline 2 & 5.16 & Medium silt & -0.08 & symmetrical & 0.68 & platykurtic \\
\hline 3 & 5.21 & Medium silt & -0.47 & very fine skewed & 0.53 & very platykurtic \\
\hline 4 & 3.77 & Medium sand & 0.09 & symmetrical & 1.06 & mesokurtic \\
\hline 5 & 3.88 & Very fine sand & 0 & symmetrical & 1.11 & leptokurtic \\
\hline 6 & 3.95 & Very fine sand & 0.26 & coarse skewed & 0.89 & platykurtic \\
\hline 7 & 4.82 & Coarse sand & -0.40 & very fine skewed & 0.88 & platykurtic \\
\hline 8 & 4.84 & Coarse sand & -0.39 & very fine skewed & 0.91 & mesokurtic \\
\hline 9 & 4.82 & Coarse sand & -0.41 & very fine skewed & 0.88 & platykurtic \\
\hline
\end{tabular}

\subsection{Coastal slope}

The slope value based on DEM data analysis had a average slope in study site was $2.46^{\circ}$. The lowest coastal slope was in zone 7 with $1.38^{\circ}$ and highest in zone 5 with $4.19^{\circ}$. All zones were classified as flat beaches (Table 7).

Based on the average range of slope in Table 7, it showed that Pangenan coast of Cirebon was classified as flat beach. The accreted beaches had slope ranging from $1.99^{\circ}$ to $3.83^{\circ}$, whereas the abrasioned beaches were ranging from $1.38^{\circ}$ to $4.19^{\circ}$. The results was related to the statement of [3] that the beaches in Cirebon have a slope ranging from $2^{\circ}$ to $4^{\circ}$. Flat beaches have high vulnerability to coastline changes $[23,6]$.

Table 3. Coastal slope in Pangenan coast of Cirebon.

\begin{tabular}{|c|c|c|}
\hline Zone & Coastal slope & Classification \\
\hline 1 & 2.2 & Flat \\
\hline 2 & 3.08 & Flat \\
\hline 3 & 1.99 & Flat \\
\hline 4 & 3.83 & Flat \\
\hline 5 & 4.19 & Flat \\
\hline 6 & 2.19 & Flat \\
\hline 7 & 1.38 & Flat \\
\hline 8 & 1.49 & Flat \\
\hline 9 & 1.83 & Flat \\
\hline
\end{tabular}




\subsection{Correlation}

The correlation between the rate of coastline changes with the characteristics of sediment and coastal slope in Pangenan coast of Cirebon based on correlation analysis, showed poor correlation and not significant. The value of significance between the rate of coastline change in 1991-1999, 1999-2017 and 1991-2017 with mean, sorting, skewness and kurtosis and coastal slope value was $>0.05$ which means there is no significant relationship between each variable. However, based on description analysis showed the tendency was accreted coastline had finer sediment and flatter slope compared to abrasion coastline.

\section{Conclusions}

Based on the discussion described above, it can be concluded that:

1) The dynamic rates of coastline change at Pangenan coast of Cirebon in 1991-1999, 1999-2017 and 1991-2017 respectively had the average accretion rate was 10.72 $\mathrm{m} /$ year, $7.25 \mathrm{~m} /$ year, $8.97 \mathrm{~m} /$ year and the average abrasion rate was $-12.49 \mathrm{~m} /$ year, $9.67 \mathrm{~m} /$ year, $-6.70 \mathrm{~m} /$ year.

2) The relation of coastline change rates, sediment characteristic and coastal slope of Pangenan coast of Cirebon based on correlation analysis had no significant relationship. However, the result tendency was accreted coastline had finer sediment and flatter slope compared to abrasion coastline

\section{References}

1. M. K. Ghosh, L. Kumar, C. Roy, ISPRS J. of Photogramm. and Rem. Sens., 101, 137144 (2015)

2. B. Triatmodjo, Teknik Pantai (1999)

3. P. Astjario, F. Harkins, J. Geologi Kelautan, 3, 19-26 (2005)

4. P. Raharjo, F. Novico. Buletin Geologi Tata Lingkungan, 22, 115-127 (2012)

5. P. D. Komar, Beach Processes and Sedimentation, (1976)

6. J. Yin, Z. Yin, J. Wang, S. Xu, J. of Coast. Conserv., 16: 123-133 (2012)

7. C. Rachmani, Rifardi, M. Galib, J. Online Mahasiswa (JOM) Bidang Perikanan dan Ilmu Kelautan, 4 (2017)

8. R. Azizul, Rifardi, M. Galib, Int. J. of Science and Research (IJSR), 6, 1945-1948 (2015)

9. G. Winarso, S. Budiman, Judijanto, 22nd Asian Conference on Remote Sensing, 1-5 (2001)

10. F. Kasim, A. Salam, J. Ilmiah Perikanan dan Kelautan, 3, 160-167 (2015)

11. Sakka, Model Perubahan Garis Pantai di Sekitar Delta Sungai Jeneberang, Makassar, Sulawesi Selatan, Disertasi, Sekolah Pasca Sarjana, Institut Pertanian Bogor, (2012)

12. E. R. Thieler, E. A. Himmelstoss, J. L. Zichichi, A. Ergul, The Digital Shoreline Analysis System (DSAS) Version 4.0 - An ArcGIS extension for calculating shoreline change (ver. 4.4, July 2017). U.S. Geological Survei, Reston. https://pubs.er.usgs.gov/publication/ofr20081278 (2017)

13. R. L. Folk, W. C. Ward, J. of Sedim. Petrol., 27, 3-26 (1957) 
14. NOAA, Environmental Sensitivity Index Guidlines Version 3.0. NOAA Technical Memorandum NOS OR\&R 11 (2002)

15. M. Arief, G. Winarso, T. Prayogo, J. Penginderaan Jauh, 8, 71-80 (2011)

16. K. M. Dewidar, O. E. Frihy, J. of Oceanog. and Marine Science, 1, 028-039 (2010)

17. B. Deepika, K. Avinash, K. S. Jayappa, Int. J. of Environ. Science and Tech., 11, 395416 (2013)

18. A. Bayhaqi, C. M. Dungga, Depik, 4, 153-159 (2015)

19. S. N. Bramha, A. K. Mohanty, M. K. Samantara, S. N. Panigrahi, K. K. Satpathy, Indian J. of Geo Marine Sciences, 46, 1562-1574 (2017)

20. T. Solahuddin, E. Triarso, R. A. Troa, J. Segara, 2, 42-48 (2006)

21. O. E. Frihy, P. D. Komar, Marine Geo., 115, 253-261 (1993)

22. B.-L. Cui, X.-Y. Li, Geomorph., 127, 32-40 (2011)

23. T. S. Kumar, R. S. Mahendra, S. Nayak, K. Radhakrishnan, K. C. Sahu, J. of Coast. Research, 26, 523-534 (2010) 